\title{
EFFECT OF SEX RATIO IN THE LITTER IN WHICH POLISH LARGE WHITE AND POLISH LANDRACE SOWS WERE BORN ON THE NUMBER OF PIGLETS BORN AND REARED
}

\author{
Anna Rekiel ${ }^{1}$, Justyna Więcek ${ }^{1}$, Monika Wojtasik ${ }^{1,4}$, Jarosław Ptak ${ }^{2}$, \\ Tadeusz Blicharski ${ }^{2}$, Leszek Mroczko ${ }^{3}$
}

\author{
${ }^{1}$ Division of Pig Breeding, Warsaw University of Life Sciences, Ciszewskiego 8, 02-786 Warsaw, \\ Poland \\ 2Polish Pig Breeders and Producers Association "POLSUS", Ryżowa 90, 02-495 Warsaw, Poland \\ ${ }^{3}$ Experimental Station of the National Research Institute Animal Production, Grodziec Śląski Ltd. \\ 43-386 Świętoszówka, Poland \\ ${ }^{4}$ The Kielanowski Institute of Animal Physiology and Nutrition, Polish Academy of Sciences, \\ Instytucka 3, 05-110 Jabłonna, Poland \\ Corresponding author: anna_rekiel@sggw.pl
}

\begin{abstract}
The aim of the study was to determine the effect of sex ratio in the litter in which Polish Large White (PLW) and Polish Landrace (PL) sows were born on the number of piglets born and reared to 21 days of age. Results obtained in nucleus herds from one breeding region were analysed. A total of 518 multiparous sows (179 PLW and 339 PL) were evaluated based on data from their litters (790 PLW and 1540 PL litters). The proportion of females in the litter in which the sow was born served as a basis for dividing the females into groups: group $1<40 \%$, group $2-40-50 \%$, group $3-50-60 \%$, group $4-60-70 \%$, group $5>70 \%$. Significant differences in the average number of piglets born were found between the groups for PLW sows; compared to sows from groups 1,2 and 3 , females from group 5 gave birth to $8.0 \%(\mathrm{P} \leq 0.05), 9.4 \%(\mathrm{P} \leq 0.01)$ and $6.6 \%$ more piglets $(\mathrm{P} \leq 0.01)$, respectively, and compared to sows from group 2, those from group 4 gave birth to $5.1 \%$ more piglets $(\mathrm{P} \leq \mathbf{0 . 0 5})$. The average number of piglets born and reared to 21 days by PL sows did not differ significantly between groups. The greater the proportion of females in the litter in which the PLW sow was born, the greater the preweaning mortality of piglets: $0.79,0.87,0.99,1.02$ and 1.24 piglets in groups 1 to 5 , respectively. Preweaning mortality of PL piglets $(0.93,0.89,0.81,0.76$ and 0.65 in groups 1 to 5 , respectively) decreased with increasing proportion of females in the litter of origin and was lower than that of PLW piglets. It seems appropriate to account for the sex ratio of the litter in which the gilts were born when selecting them as mothers of the next generation as part of herd replacement; this parameter may improve fertility and production efficiency.
\end{abstract}

Key words: sex ratio, sows, litter size 
Adjacent fetuses produce a hormonal environment which leaves a lasting mark on the body of females born. Prenatal androgen exposure leads to subsequent reproductive problems in gilts and sows (Drickamer et al., 1997, 1999; Ryan and Vandenbergh, 2002; Hotchkiss et al., 2007). Literature studies on the subject show that females undergo changes in the structure of external genitalia and anogenital distance, which may cause fertilization failure and inhibit the development of teats (Rekiel et al., 2010). Rohde Parfet et al. (1990 a) studied the impact of intrauterine position effects in female pigs on parameters such as subsequent reproductive performance, and social and sexual behaviour. In another experiment, they investigated intrauterine position effects in male and female pigs on subsequent survivability, growth rate, morphology and semen characteristics (Rohde Parfet et al., 1990 b). A relationship was found between the sex of adjacent fetuses and reproductive capacity; in multifetal species, $0 \mathrm{M}$ females (adjacent to female fetuses) reached maturity more rapidly and came into oestrus sooner than $2 \mathrm{M}$ females (adjacent to male fetuses) (Drickamer et al., 1997; Huehn et al., 2002; Orzechowska et al., 2002; Vandenbergh, 2003). The results indicate that prenatal intrauterine position has little effect on adult agonistic behaviour, length of the oestrus cycle and ovulation rate, but may affect the subsequent sexual behaviour of female pigs (Rohde Parfet et al., 1990 a). Because blood flows through the uterus in one direction in pigs, Ryan and Vandenbergh (2002) hold that the number of fetuses of the same sex in the uterine horn has a greater effect on reproductive capacity of the next generation's gilts compared to the effects of intrauterine position and proximity of fetuses. The findings of Huehn et al. (2002), Orzechowska et al. (2002) and Vandenbergh (2003) also confirm this relationship. The sex ratio of litters in which replacement animals were born may provide a basis for predicting the potential lifetime productivity of gilts. The results of studies conducted in the 1990s demonstrate considerable variation in this area. This concerns potential fertility, sexual and social behaviour of gilts, and litter uniformity (Walkiewicz and Stasiak, 1988; Rohde Parfet et al., 1990 a; Owsianny et al., 1991; Stasiak, 1996).

Comprehensive evaluation of females in breeding herds, which includes performance testing of gilts (Eckert and Żak, 2011), evaluation of reproductive performance in sows (Orzechowska and Mucha, 2011) and estimation of breeding value using BLUP (Orzechowska et al., 2011), fails to account for the effect of sex ratio in the litter in which the sow was born on its reproductive performance.

The aim of the study was to determine the effect of female sex ratio of the litter in which multiparous Polish Large White and Polish Landrace sows were born on the number of piglets born and reared per litter to 21 days of age.

\section{Material and methods}

Data on reproductive performance of 518 multiparous sows (179 Polish Large White and 339 Polish Landrace), used in nucleus herds in one breeding region, were analysed. Reproductive parameters were determined based on litters born to the sows 
(790 PLW and 1540 PL litters). Based on the proportion of females in the litter in which the sows were born, females were divided into group $1(<40 \%)$, group 2 (40-50\%), group $3(50-60 \%)$, group $4(60-70 \%)$, and group $5(>70 \%)$. The results obtained were analysed statistically using one-way analysis of variance with the least squares method. Results were presented in tables as mean values of parameters, standard errors of the means and the statistical significance of the group (SPSS 2009).

\section{Results}

Compared to females from groups 1, 2 and 3, PLW sows from group 5 gave birth to $8.0 \%(\mathrm{P} \leq 0.05), 9.4 \%(\mathrm{P} \leq 0.01)$ and $6.6 \%$ more piglets $(\mathrm{P} \leq 0.01)$, respectively, and compared to sows from group 2, PLW sows from group 4 gave birth to $5.1 \%$ more piglets $(\mathrm{P} \leq 0.05)$ (Table 1$)$. No statistically significant differences were found between groups in the average number of piglets reared to 21 days, and sows from litters with more females $(>50 \%)$ tended to wean larger litters. The greater the proportion of females in the litter in which the PLW sow was born, the greater the average preweaning mortality of piglets: $0.79,0.87,0.99,1.02$ and 1.24 piglets in groups 1 to 5 , respectively.

Table 1. Selected traits of reproductive performance in PLW sows

\begin{tabular}{|c|c|c|c|c|c|c|c|}
\hline \multirow{4}{*}{ Trait } & \multicolumn{5}{|c|}{ Proportion of females in the litter $(\%)$} & \multirow{4}{*}{ Total } & \multirow{4}{*}{ SEM } \\
\hline & $<40$ & $40-50$ & $50-60$ & $60-70$ & $>70$ & & \\
\hline & \multicolumn{5}{|c|}{ Group } & & \\
\hline & 1 & 2 & 3 & 4 & 5 & & \\
\hline Number of sows (n) & 16 & 37 & 61 & 41 & 24 & 179 & \\
\hline Sows ratio in the group $(\%)$ & 8.9 & 20.7 & 34.1 & 22.9 & 13.4 & 100 & \\
\hline Piglets born in total (head) & $11.43 \mathrm{a}$ & $11.29 \mathrm{Ab}$ & $11.58 \mathrm{~B}$ & $11.86 \mathrm{~b}$ & $12.35 \mathrm{ABa}$ & 11.67 & 0.216 \\
\hline Piglets reared to 21 days (head) & 10.64 & 10.42 & 10.59 & 10.84 & 11.11 & 10.68 & 0.173 \\
\hline
\end{tabular}

$\mathrm{a}, \mathrm{b}-\mathrm{P} \leq 0.05 ; \mathrm{A}, \mathrm{B}-\mathrm{P} \leq 0.01$.

Table 2. Selected traits of reproductive performance in PL sows

\begin{tabular}{|c|c|c|c|c|c|c|c|}
\hline \multirow{4}{*}{ Trait } & \multicolumn{5}{|c|}{ Proportion of females in the litter $(\%)$} & \multirow{4}{*}{ Total } & \multirow{4}{*}{ SEM } \\
\hline & $<40$ & $40-50$ & $50-60$ & $60-70$ & $>70$ & & \\
\hline & \multicolumn{5}{|c|}{ Group } & & \\
\hline & 1 & 2 & 3 & 4 & 5 & & \\
\hline Number of sows (n) & 18 & 48 & 110 & 110 & 53 & 339 & \\
\hline Sows ratio in the group (\%) & 5.3 & 14.1 & 32.5 & 32.5 & 15.6 & 100 & \\
\hline Piglets born in total (head) & 11.65 & 11.62 & 11.51 & 11.47 & 11.39 & 11.53 & 0.078 \\
\hline Piglets reared to 21 days (head) & 10.72 & 10.73 & 10.70 & 10.71 & 10.74 & 10.72 & 0.068 \\
\hline
\end{tabular}


The average number of piglets born and reared to 21 days by PL sows did not differ significantly between groups 1 to 5 (Table 2). Preweaning mortality of PL piglets $(0.93,0.89,0.81,0.76$ and 0.65 in groups 1 to 5 , respectively) decreased with increasing proportion of females in the litter.

\section{Discussion}

The results obtained in our study are substantiated by the intrauterine position phenomenon (proximity of fetuses to male or female siblings), the effect of hormones they produce on changes in morphological, physiological and behavioural traits of adjacent fetuses, and the unidirectional flow of blood through the uterus (Orzechowska et al., 2002; Ryan and Vandenbergh, 2002; Hotchkiss et al., 2007; Hurd et al., 2008). The embryo sex ratio at conception is $1: 1$, with minor deviations from the binomial distribution (Toro et al., 2006). This sex ratio is found in nature, with approximately $90-95 \%$ of litters having the 1:1 ratio (Orzechowska et al., 2002; Toro et al., 2006).

In our study, the male to female ratio was 4.97:6.19 (24.6\% more females than males) for litters in which PLW sows were born, and 4.81:6.57 (36.6\% more females than males) for litters in which PL sows were born. This means that the male to female ratio was 45:55 for the PLW breed and 42:58 for the PL breed. Compared to female fetuses, male fetuses are more sensitive to changes in intrauterine conditions, and thus more susceptible to perinatal mortality (Ryan and Vandenbergh, 2002; Górecki and Kościński, 2003; also Chen and Dziuk (1993) and Catalano et al., (2008) cited from Rekiel and Wojtasik, 2010). The literature on the subject partly presented above explains the fact that in our study in the PLW breed, there were fewer (29.6\%) females from litters with more males (groups 1 and 2), and more (70.4\%) sows from litters with fewer males (groups 3 to 5); the respective values for the PL breed were $19.5 \%$ and $80.5 \%$.

The litter sex ratio in mammals is affected by various factors such as steroid hormones and estradiol levels in female urine, the interval from ovulation to fertilization, differences in embryo mortality, the type and quality of food consumed by the mother, the age and condition of parents, position in the social hierarchy, the month of mother's birth, litter size, stress factors, population history, and intrauterine position (Górecki, 2003; Górecki and Kościński, 2003). Animals in good condition or those occupying high positions in the social hierarchy invest in male progeny to maximize their own reproductive success. Dominant female domestic pigs give birth to more males (up to 59\%) in litters compared to low-ranking sows (approximately 41\%) (Meikle et al., 1993, 1996; Mendl et al., 1995; Cieplak, 1999 cited from Rekiel and Wojtasik, 2010).

Ryan and Vandenbergh (2002) and Toro et al. (2006) suggest that type of birth may be heritable. However, the coefficient of correlation, calculated by Górecki and Kościński (2003) between sex ratio in the first and second litter was non-significant and negative $(\mathrm{P}=0.061, \mathrm{r}=-0.25)$. 
Litter size has an effect on sex of progeny, with a lower proportion of males in large litters (Górecki, 2003). The same author also observed that females born between September and February have a greater proportion of males per litter compared to those born between March and August.

Walkiewicz et al. (2000) analysed the sex ratio of piglets in litters from PL breeding sows and the relationship between litter traits, growth and development of gilts, slaughter value expressed in terms of daily gains and meat percentage, as well as their reproductive performance. Our results partly confirm the findings of the authors quoted above. Sows from litters with a 1:1 sex ratio (Walkiewicz et al., 2000) or with at least $50 \%$ of females per litter (PLW breed in our study) achieved better results in terms of reproductive performance, as expressed by the number of piglets per litter at 1 and 21 days of age, compared to sows from litters with more males. The results of studies by Ryan and Vandenbergh (2002), Salazar-Martinez et al. (2004), Weiss (2006) and Hurd et al. (2008) show that in different multifetal species, females from litters with more females than males reached sexual maturity and conceived more rapidly, gave birth to more offspring, and had longer reproductive lifespans. Our study did not confirm the effect of sex ratio of the litter in which the sow was born on reproductive parameters of PL females. This may be associated with different histories of the PLW and PL populations that we investigated. This thesis is supported by Górecki (2003) and Górecki and Kościński (2003).

Walkiewicz et al. (2000) report that the shortest reproductive life is found in sows from litters with $25 \%$ females and $75 \%$ males. However, compared to other birth types, gilts originating from such litters are characterized by better fattening (daily gains) and slaughter traits (carcass meat content). Compared to the other birth types, these values are greater by $97-110 \mathrm{~g} /$ day and $1.2-2.0 \%$ meat, respectively.

According to Foxcroft et al. (2009), the potential use of genomics, epigenomics, nutrigenomics, and proteomics to investigate these mechanisms brings new demands on experimental design and data management that present a considerable challenge to the effectiveness of future research on prenatal programming in the pig. Foxcroft et al. (2006) believe that a strategy of introducing hyperprolific females into the breeding nucleus, as a means of increasing the numbers of pigs born, needs to be critically evaluated in the context of the overall efficiency of pork production.

The number of piglets born and reared per litter by sows from litters with more males than females, which was higher for PLW sows and comparable for PL sows, suggests that it is appropriate to pursue further research on this topic and to perform analyses on a greater number of animals. Our results indicate that the sex ratio of the litter in which the gilts were born should be considered when selecting them as mothers as part of herd replacement, because this parameter does not adversely affect fertility.

\section{References}

Drickamer L.C., Arthur R.D., Rosenthal T.L. (1997). Conception failure in swine: importance of the sex ratio of a female's birth litter and tests of other factors. J. Anim. Sci., 75: 2192-2196. 
Dri ck a mer L.C., R o s e n thal T.L., A r thur R.D. (1999). Factors affecting the number of teats in pigs. J. Reprod. Fertil., 115: 97-100.

E cke r t R., Żak G. (2011). Results of performance tested gilts. Report on pig breeding in Poland in 2010. Kraków, XXIX: 34-44.

Foxcroft G.R., Dixon W.T., Dyck M.K., Novak S., Harding J.C., Almeida F.C. (2009). Prenatal programming of postnatal development in the pig. Soc. Reprod. Fertil., Suppl., 66: 213-231.

Fox croft G.R., Dix on W.T., Novak S., Putman C.T., Town S.C., Vinsky M.D. (2006). The biological basis for prenatal programming of postnatal performance in pigs. J. Anim. Sci., Suppl., 84: E105-112.

G ó r e c k i T. (2003). Sex ratio in litters of domestic pigs (Sus scrofaf. domestica Linnaeus, 1758). Biol. Lett., 40: 111-118.

Górecki T., Kościński K. (2003). Offspring sex ratio in domestic goat (Capra hircus). Arch. Tierzucht., 46: 277-284.

Hotchkiss A.K., Lambright C.S., Ostby J.S., Parks-Saldutti L., Vandenb e r g h J.G., G r a y L.E. Jr. (2007). Prenatal testosterone exposure permanently masculinizes anogenital distance, nipple development, and reproductive tract morphology in female Sprague-Dawley rats. Toxicol. Sci., 96: 335-345.

Huehn H., Tuchscherer A., Breite L., Grodzycki M., Huehn U. (2002). Influence of base litter sex ratio of gilts on their subsequent reproductive performances. Zuchtungskunde 74 : $56-69$.

Hurd P.L., B a i l e y A.A., G ong a 1 P.A., Y a n R.H., Gre er J.J., P a g li ard in i S. (2008). Intrauterine position effects on anogenital distance and digit ratio in male and female mice. Archiv. Sexual Behav., 37: 9-18.

Orzechowska B., Much a A. (2011). Results of reproductive performance of breeding sows. Report on pig breeding in Poland in 2010. Kraków, XXIX: 3-18.

Orzechowska B., Tyra M., Mucha A. (2002). Reproductive performance of sows from litters of various sex ratio. Ann. Anim. Sci., 2: 155-159.

Orzech ow sk a B., Ty ra M., M u cha A. (2011). Evaluation of pig breeding value using the BLUP method. Reproductive performance. Kraków, VII: 1, 3-6.

Owsianny J., Wejksza D., Czarnecki R. (1991). Reproductiveness of gilts originated from litters with the different participation of young boars. Abstr. 42nd Ann. Meet. EAAP, 8-12.09.1991, Berlin, 2, p. 473.

Rekiel A., Więcek J., Wojtasik M., Kulis iew i c z J., B atorska M. (2010). The internal environment and reproduction in multifetal species (in Polish). Rocz. Nauk. Zoot., Monogr. Rozpr., 44: 79-88.

R e k i e l A., W o j t a s i k M. (2010). Sex ratio in populations in terms of maximization of reproductive success (in Polish). Rocz. Nauk. Zoot., Monogr. Rozpr., 44: 113-126.

Rohde Parfet K.A., Ganjam V.K., Lamberson W.R, Rieke A.R., vom Saal F.S., D a y B.N. (1990 a). Intrauterine position effects in female swine: subsequent reproductive performance, and social and sexual behavior. Appl. Anim. Behav. Sci., 26, 4: 349-362.

Rohde Parfet K.A., L a mbers on W.R., R i eke A.R., Cent lez T.C., G a n j a m V.K., vom $\mathrm{S}$ a a 1 F.S., D a y B.N. (1990 b). Intrauterine position effects in male and female swine subsequent survivability, growth rate, morphology and semen characteristics. J. Anim. Sci., 68, 1: 179-185.

R y a n B.C., V a nd e $n$ bergh J.G. (2002). Intrauterine position effects. Neurosci. Biobehav. Rev., 26: 665-678.

Salazar-Martinez E., Romano-Riquer P., Yanez-Marquez E., Longnecker M.P., Hernandez-Avila M. (2004). Anogenital distance in human male and female newborns: a descriptive, cross-sectional study. Environ. Health, 3, p. 8.

SPSS 2009. User's Guide 12.0. SPSS Inc.

Stasiak A. (1996). Interdependence between sexual activity of gilts during oestrus, development of reproductive organs, and potential and actual fertility (in Polish). Rozpr. Nauk. Wyd. AR Lublin.

Toro M.A., Fernández A., García-Cortés L.A., Rodrigáñez J., Silió L. (2006). Sex ratio variation in Iberian pigs. Genetics, 173: 911-917. 
Vandenbergh J.G. (2003). Prenatal hormone exposure and sexual variation. Am. Scientist, 91: $218-225$.

Walkiewicz A., B abicz M., Kasprzyk A., Dziura J. (2000). Analysis of piglet sex distribution in litters from PL breeding sows and the relationship between litter traits and reproductive performance of gilts reared. Ann. UMCS, sectio EE Zootech., 18: 61-68.

W a l k i ew i c z A., S t a s i a k A. (1988). Variation in uniformity of litters from breeding sows of the Puławska and Polish Large White breeds (in Polish). Zesz. Probl. Post. Nauk Rol., 335: 135-141.

W e is s B. (2006). Anogenital Distance: Defining "Normal”. Environ. Health Perspect., 114, p. 399.

Accepted for printing 7 III 2012

\title{
ANNA REKIEL, JUSTYNA WIĘCEK, MONIKA WOJTASIK, JAROSŁAW PTAK, TADEUSZ BLICHARSKI, LESZEK MROCZKO
}

\author{
Wpływ udziału płci w miocie pochodzenia loch rasy wielkiej białej polskiej i polskiej białej \\ zwisłouchej na liczbę prosiąt urodzonych i odchowanych
}

\section{STRESZCZENIE}

Celem pracy była ocena wpływu udziału płci w miocie pochodzenia loch rasy wielkiej białej polskiej i polskiej białej zwisłouchej na liczbę prosiąt urodzonych i odchowanych do 21. dnia życia. Analizowano wyniki uzyskane w stadach zarodowych z jednego rejonu hodowlanego. W ocenie loch wieloródek - 179 rasy wbp i 339 rasy pbz - podstawą były informacje pozyskane dla pochodzących od nich miotów; łącznie było to 790 miotów wbp i 1540 pbz. Udział osobników płci żeńskiej w miocie pochodzącym od lochy-matki był podstawą podziału samic na grupy: grupa $1<40 \%, 2-40-50 \%$, $3-50-60 \%, 4-60-70 \%, 5>70 \%$.

Dla loch wbp wykazano między grupami istotne różnice w średniej liczbie prosiąt urodzonych; samice $\mathrm{z}$ grupy $5 \mathrm{w}$ porównaniu do loch $\mathrm{z}$ grup 1, 2 i 3 urodziły więcej prosiąt, odpowiednio o: 8,0\% $(\mathrm{P} \leq 0,05), 9,4 \%(\mathrm{P} \leq 0,01), 6,6 \%(\mathrm{P} \leq 0,01)$, a $\mathrm{z}$ grupy 4 vs. 2 o $5,1 \%(\mathrm{P} \leq 0,05)$. Średnia liczba prosiąt urodzonych i odchowanych do 21 . dnia przez lochy pbz nie różniła się istotnie pomiędzy grupami. Im większy był udział samic w miocie pochodzenia loch rasy wbp, tym większe były upadki prosiąt w czasie odchowu; w grupach $1-5$ odpowiednio: $0,79,0,87,0,99,1,02,1,24$ szt. Dla rasy pbz przy zwiększającym się udziale samic w miocie pochodzenia upadki prosiąt podczas odchowu przy matkach malały, przy czym ich poziom był mniejszy niż dla rasy wbp; w grupach 1-5 wyniosły odpowiednio: 0,93, 0,89, 0,81, 0,76, 0,65 szt. Wydaje się uzasadnione uwzględnienie udziału płci w miocie pochodzenia loszek przy ich wyborze na przyszłe matki w ramach prowadzonego remontu stada; cecha ta może poprawiać płodność i efektywność produkcji. 